\title{
Terminology Development at Tertiary Institutions: A South African Perspective
}

\author{
Mariëtta Alberts, Research Unit for Languages and Literature in SA Context, \\ North-West University, Potchefstroom Campus, Potchefstroom, \\ South Africa (AlbertsMarietta@gmail.com)
}

\begin{abstract}
There is a dire need in South Africa for multilingual polythematic terminology. Currently no tertiary institution presents terminology theory and practice as a fully-fledged subject and there is also no sufficient mechanism for the training of terminologists. This situation provides tertiary institutions the opportunity to position themselves in terms of terminology training and development. Terminology centres at tertiary institutions could be of great value for language as well as all other subject-related departments. The language departments, where such terminology centres could possibly be housed, already have facilities to teach some or all of the official languages of South Africa at tertiary level. Language students could receive postgraduate (and even undergraduate) training in the theory and practice of terminology. For practical work, they could collect terminology at subject-related departments and take it to the terminology centres, where source language terms could be terminographically treated. Subject specialists (i.e. lecturers teaching different subjects) would have to be consulted when defining the concepts and would have to assist language students and their lecturers to supply term equivalents in target languages. This process would enable subject-related and language departments to cooperate in different domains. Language and language departments would therefore become useful to different subject areas. Multilingual polythematic terms with definitions could be available to students who are not proficient in English or Afrikaans. They would therefore have access to study material in their first language. The terminology could be disseminated internally and (inter)nationally through the Internet, which would make it accessible to any other student. This process could best be managed and executed by dedicated terminology centres.
\end{abstract}

Keywords: LEGISLATION, MULTILINGUAL TERMINOLOGY, POLYTHEMATIC TERMINOLOGY, SOURCE LANGUAGE, STANDARDISATION, TARGET LANGUAGE, TERMINOGRAPHY, TERMINOLOGY, TERMINOLOGY CENTRE, TERMINOLOGY DEVELOPMENT, TERMINOLOGY TRAINING

Opsomming: Terminologieontwikkeling aan tersiêre instansies: 'n SuidAfrikaanse perspektief. Daar bestaan in Suid-Afrika ' $n$ groot behoefte aan meertalige terminologie op verskeie vakgebiede. Tans bied geen tersiêre instansie terminologieteorie en -praktyk as volwaardige vak aan nie en daar is nie 'n doeltreffende meganisme waarvolgens terminoloë opgelei kan word nie. Hierdie situasie skep die geleentheid vir tersiêre instansies om hulself te posisioneer ten opsigte van terminologieopleiding en -ontwikkeling. Terminologiesentra aan tersiêre instansies sal vir taal- sowel as alle ander vakgerigte departemente van onskatbare waarde wees. Die 
taaldepartemente, waar sodanige sentra waarskynlik gehuisves sou kon word, beskik reeds oor fasiliteite om sommige of alle amptelike tale van Suid-Afrika op tersiêre vlak aan te bied. Taalstudente kan nagraadse (en selfs voorgraadse) opleiding kry in terminologieteorie en -praktyk. As praktiese werk sou hulle terminologie by vakgerigte departemente kon gaan versamel en na die sentra neem waar die brontaalterme terminografies hanteer kan word. Vakkundiges (bv. lektore wat vakke aanbied) sal met die definiëring van konsepte behulpsaam moet wees en sal saam met die taalstudente en -dosente vertaalekwivalente in doeltale moet verskaf. Dié proses sal meebring dat vakkundiges en taalkundiges oor vakgrense heen saamwerk. Dit sal daartoe lei dat taal en taaldepartemente vir ander vakterreine van waarde sal raak. Meertalige vakgerigte terme met definisies sal beskikbaar wees vir studente wat nie Engels of Afrikaans magtig is nie. Hulle sal dus toegang tot studiemateriaal in hul eerste taal kan kry. Die terminologie kan intern deur die tersiêre instansies en (inter)nasionaal deur die Internet versprei word, wat dit toeganklik sal maak vir enige ander student. Hierdie proses kan ten beste deur doelgerigte terminologiesentra beheer en uitgevoer word.

Sleutelwoorde: BRONTAAL, DOELTAAL, MEERTALIGE TERMINOLOGIE, STANDAARDISERING, TERMINOGRAFIE, TERMINOLOGIE, TERMINOLOGIEOPLEIDING, TERMINOLOGIEONTWIKKELING, TERMINOLOGIESENTRUM, VAKGERIGTE TERMINOLOGIE, WETGEWING

\section{Introduction}

Terminology plays a pivotal role in the teaching and learning of subject matter. Terminology is a tool for communication in languages for special purposes, e.g. subject areas (mathematics, physics, chemistry, botany, zoology) and domains (art, music, sport).

Specialised information is encoded in a source language to be conveyed (transmitted) from a sender as communication source (e.g. lecturer) to a receiver as recipient of information (e.g. student), who will decode the message and then react on the stimulus received. Terminology allows subject-related communication between subject specialists and between subject specialists and laypeople (cf. Alberts 2012b).

Lecturers (as subject specialists) teach a specific subject (e.g. physics) to students (laypeople) to equip them to become subject specialists themselves and to enable them to serve as knowledgeable workers in a vocation-specific environment. This argument is only valid if the subject specialist is able to convey information to the student. Lecturers should be educated to respond to "desired" mother-tongue education (cf. Maseko 2012: 5).

Most South African tertiary institutions primarily use English as language of learning and teaching, and sometimes Afrikaans. It is argued that Afrikaans had the opportunity to develop as an academic language during the previous political dispensation. Even African languages as subjects are taught largely through the medium of other languages (cf. Maseko 2012: 3).

There are several arguments underpinning the value of instruction through the mother tongue or first language of both trainer and trainee. It is, however, currently not possible to supply mother-tongue/first language education in 
South Africa during the tertiary phase of education. There are several reasons for this situation, but this article will only focus on ways to solve the need for multilingual terminology in various subject-related areas at tertiary institutions.

\section{Relevant legislation}

According to Census 2011 results, only 9,6\% of the South African population speak English as their first language, while the rest of the population speak other languages as their first language. Given that the majority of South Africans are not first-language speakers of English, the implication is that they would have limited or no access to information, an important commodity for participation and democracy (cf. Statistics South Africa 2013: iii). The value of available standardised multilingual polythematic terminology cannot be overemphasised. The need for such terminology is probably greater in South Africa than in other countries, seeing that we have a multilingual dispensation encapsulated in the Constitution of the Republic of South Africa, 1996.

The Constitution of the Republic of South Africa, 1996, provides for the equitable use of all the official languages of the country, and for the promotion and development of the historically marginalised indigenous languages. The National Language Policy Framework of March 2003 gives effect to the constitutional rights regarding language usage and development (cf. Department of Sport, Recreation, Arts and Culture 2005: 1,3).

Section 6(2) of the Constitution of the Republic of South Africa, 1996, recognises the historically diminished use and status of the indigenous languages of South Africa, and compels the state to take practical steps to design mechanisms to elevate the status and to advance the use of these languages (cf. Department of Sport, Recreation, Arts and Culture 2005: 3). The Constitution further requires all official languages to enjoy parity of esteem and to be treated equitably. It also provides for national government to regulate and monitor the use of official languages by legislative and other means (cf. Department of Arts and Culture 2011: 7; Government Gazette 2012: 2, 4). The Use of Official Languages Act, 2012 (Act No. 12 of 2012) stipulates that every national department, national public entity and national public enterprise should promote the use of official languages in facilitating access to services and information. They should furthermore develop a language policy regarding their use of official languages, amongst others, in effectively communicating with the public, official notices, government publications and inter- and intra-government communications (cf. Government Gazette 2012: 6; cf. Regulation 7(1)(d) Government Gazette 2013: 25). The development of multilingual terminology for the official languages gives effect to the constitutional rights of languages regarding their usage and their further development.

It is clear that political change in 1994 provided a legislative context for transformation in all phases of education and a redress of imbalances resultant from the previous dispensation (cf. Maseko 2012: 3). Language, amongst other 
issues, is seen as critical in fostering transformation in higher education and in society. The role of English and Afrikaans as languages of higher learning is acknowledged but tertiary institutions should not exclude nor discriminate against speakers of other languages (cf. Maseko 2012: 4). The development of all official languages to address imbalances of the past is a legislative imperative and is reflected in the legislative context of the Constitution of the Republic of South Africa (1996); Higher Education Act (1997); National Plan for Higher Education (2001); Language Policy for Higher Education (2002); the Ndebele Report on the Development of Indigenous African Languages as Mediums of Instruction in Higher Education (2003); Development of Indigenous languages as Mediums of Instruction in Higher Education (Report compiled by the Ministerial Committee appointed by the Ministry of Education) (2003); Humanities and Social Sciences Charter (2011) and the Green Paper on Post-secondary School Education and Training (2012) (cf. Maseko 2012: 4-5, 34-36).

Section 27(2) of the Higher Education Act (101 of 1997) requires the Minister to determine language policy for Higher Education. Subject to the policy, Councils of public higher education institutions, with the concurrence of their Senates, must determine the language policy of an institution and publish and make the policy available on request. The main objective of the Language Policy for Higher Education (Section 6, 2002) is to promote multilingualism in institutional policies and practices of universities:

The challenge facing higher education is to ensure the simultaneous development of a multilingual environment in which all our languages are developed as academic/scientific languages, while at the same time ensuring that the existing languages of instruction do not serve as a barrier to access and success (cf. Department of Higher Education and Training 2010: 3-6).

The Green Paper on Post-secondary school Education and Training, 2012, par. 6.10 recognises the unfortunate position of African languages in South African Higher Education and provides for African languages to be utilised across disciplines at tertiary institutions (cf. Department of Higher Education and Training 2012; Maseko 2012: 6). No subject could, however, be taught without relevant subject-specific terminology. Without proper subject-specific terminology in the language(s) of choice, the principle of having a shared language of learning and teaching would remain a pipedream.

Terminology development adheres to the language policy of the country. In the previous dispensation, with a bilingual policy, terms were supplied in English and Afrikaans. Since 1994 the Republic of South Africa has had a multilingual policy and therefore terminology should be available in the 11 official languages. Terms should also be available in South African Sign Language (SASL) - in this case signs to denote the underlying concepts (cf. Alberts 2012a).

The following arguments are valid for advancing the use of multilingual terminology in higher education:

— Pedagogic argument — the link between language and cognition in terms 
of multilingualism in education.

- Economic argument - economic participation both locally and globally, and the resultant social mobility.

- Socio-cultural argument - identity of "self" in the context of "others".

- Linguistic argument - language development/study which, if not undertaken, is a threat to linguistic diversity, and could lead to language decline or death.

- Political argument - nation building, which emphasises unity in diversity; equity, access, success, redress, language rights and transformation (cf. Maseko 2012: 10).

The Language Policy for Higher Education (2002) highlights the need to promote South African languages for use in instruction in higher education. It also stresses the need to develop strategies for promoting proficiency in languages of tuition. It furthermore encourages all tertiary institutions to consider ways of promoting multilingualism and requires institutions to indicate in their plans what strategies have been put in place (cf. Department of Higher Education and Training 2010: 7-8).

A 2011-2012 survey on language choices regarding the language policies of tertiary institutions found that 17 out of 23 universities have published their language policies and all institutions surveyed have selected at least one indigenous African language as another language of learning and training. The implementation plans, especially on the promotion and development of the African languages were, however, lacking (cf. Maseko 2012: 8).

Afrikaans is an example of a language that was initially regarded as a "kitchen language" but which developed into a functional language in inter alia science, technology, economy and education. There is therefore no reason why the other official languages could not develop into languages of higher learning. Because of the hegemony of English, the other official languages often struggle with terminology development. Most terms denoting new concepts reach South Africa through the medium of English and special efforts need to be made to translate these terms into the various official languages (cf. Alberts 2012a).

By developing subject-specific terminology in all official languages and by compiling multilingual polythematic term lists/glossaries/dictionaries and other supporting teaching resources (i.e. multilingual study material that incorporates the multilingual terminology) the process to develop the official languages into scientific languages will be facilitated. Academic proficiency in the language of learning and teaching will also be promoted.

\section{Terminological principles}

It is a given that one understands concepts best in one's first language. It is also 
easier to convey information (e.g. teach/train) through the medium of the first language of both the lecturer/trainer and the student/trainee. Lecturers who understand the subject matter in their first language will be able to convey the information to students. Conceptualisation is also paramount in the first language/mother tongue (cf. Alberts 2012a).

Students at tertiary institutions are confronted by different subjects that contain difficult subject matter to be comprehended. What makes this issue even worse is that these subjects are often taught in many lecturers' and students' second or third language. Terminology is not always available in the different subject areas and the different official languages. The same concept is often denoted by means of different terms (cf. digestive tracts/gastrointestinal tract/alimentary canal), which leads to confusion. The increasing use of nonstandardised terms in the lecture hall often has dire consequences for students and for the subject and language in question.

When terminology is developed, one should adhere to basic terminological principles:

- A concept is denoted by means of a term.

- A term has an exact meaning and has to denote the features of the concept it represents.

- A term therefore refers to a definite concept which is clearly defined within specific parameters.

- A term is a linguistic representation of a mental construct (cf. Alberts 2012b).

Terminology can be regarded as any of the following:

- a collection of terms in a specialised subject area or domain

- the methods used to harvest, document, systematise, standardise and disseminate terms

- the science researching the nature of terms, their form and communicative function (Cluver 1983: 7).

The primary aim of terminology is to promote communication in scientific and technological environments. Terms are documented and systematised in order to compile technical dictionaries, language for special purpose (LSP) dictionaries, glossaries, terminology lists, electronic term banks, or online dictionaries (Alberts 2012b).

Terminography is an interdisciplinary practice that combines areas such as lexicographical principles, linguistics, information science, ontologies, computational linguistics, computer science, etc.

Terminology uses the grammar and orthography (cf. tree (en) vs. Baum (de) (nouns are capitalised in German)) of the standard variety of the language. 
Terms are created according to the word-forming principles of the standard variety of the language (cf. Alberts 2012b).

Specialised terms are needed

- that provide access to texts in other languages, e.g. source language (SL) to target language(s) (TL(s))

- that have exact meaning with no emotional connotations

- that function within a specific conceptual cluster

— that are standardised (e.g. 1 = one, een, uno, eins, kunye, nye, nngwe, ...)

- that always denote the same concept (e.g.

subtract (-) $v$. aftrek; ntsha; ntsha; tlosa; thabatha; susa; khokha; khupha; u tusa; susa)

- that are harmonised in related (inter)national languages (e.g.

macroinstruction (en); makroinstruksie (af); makroinstruktion (da); macroinstrução (pt))

- that are harmonised in related South African languages (e.g.

count (v.): tel (af); bala (ns); bala (ss); bala (tn); bala (xh); bala (zu); bala (nd); -vhala (ve); ku hlayela (ts)

litre (n.) $\langle\ell>$ : liter (af); ilitha (xh); ilitha (zu); ilitha (sw); ilitha (nd); litha (ve); litara (ns); litara (ss); litara (tn); litara (ts).

Concepts should be defined in the source language (SL) and terms should be created in the SL to denote the concept (process: primary term creation). Only then term equivalents could be supplied in target language(s) (TLs) (process: secondary term creation) (cf. Alberts 2012a), e.g.

straight line (en) The shortest distance between two points. reguit lyn (af); umugqa ogonde thwi (zu); umgca ongqalileyo (xh); umugca locondzile (ss); umudathwi (nd); molatlhamalalo (tn); mothalothwii (ns); mola o otlolohileng (st); mutalo tswititi (ve); layini-thwi; layini yo ololoka (ts).

The terminographical process entails the following:

- demarcation of the subject area or domain

- determining of the target user group

- collection of terms from relevant sources (e.g. text books, dissertations, journals, study material, etc.)

- excerption of relevant terms, i.e. harvesting of source language (SL) terms

- defining of terms in the SL (e.g. English) and providing of contextual sentences and related information (i.e. parts of speech)

— verifying of the SL information with subject specialists 
- changing of the database according to input received

- adding of target language (TL) equivalent(s) and related information (e.g. definitions, example sentences, parts of speech, etc.)

- verifying of TL term equivalents and related information with the relevant Technical Committee (TC) of the relevant National Language Body (NLB) for its stamp of approval of the linguistic content

- adjusting and updating of the database according to suggestions received

- dissemination of the SL terms and TL equivalents with related data to target users via hard copy publications (term lists, glossaries), electronic dictionaries (CD ROM, online, Internet), documents containing terms (textbooks, study guides, dissertations, manuals, journals, technical brochures, etc.), mass communication media (radio, press, television, etc.).

Terminology assists with subject-related communication. Terminology is documented with the aim of providing subject specialists (lecturers) and laypeople (students) with standardised terms that denote the corresponding concepts.

Terminology should be standardised to allow exact communication. The standardisation process entails that the majority of subject specialists should agree to denote a definite concept with a specific term through

- the limiting of meaning by means of a proper definition within the conceptual cluster of the subject area - one term should denote one concept and one should try to avoid the use of synonyms

- the systematisation and usage of language rules, e.g. grammar, wordforming principles, spelling and orthographic rules, and the consultation of linguists, since they play an important role in the standardisation process

- the submission of the SL terms and TL term equivalents to the relevant National Language Body (NLB) for the linguistic verification and approval of the terms

- the dissemination of terms (dictionaries or online facilities) to ensure usage and the penetration of terms in the relevant subject area or domain and in different languages (cf. Cluver 1982: 81; Alberts 2012a).

Terms that are not standardised, give rise to communication problems. It should, however, be noted that standardisation is a process that takes time. Terms will only become standardised when they are used properly and penetrate the subject area or domain and the specific language through frequent usage.

\section{Models for terminology development for the tertiary phase of education}

One could ask what could be done to solve terminology needs and to develop terminology for usage by lecturers and students at tertiary institutions. Dedi- 
cated terminology institutions, publishing houses, private initiatives and tertiary institutions could all develop terminology to address the need for multilingual polythematic terminology at tertiary institutions. Three terminographical models will be discussed, but special emphasis will be placed on terminology training and development by tertiary institutions themselves. An integrated working model will also be presented.

\subsection{Dedicated terminology offices}

There are several terminology offices in South Africa that are dedicated to the development of vocation-specific terminology. The following offices serve as examples of dedicated terminology offices:

\subsubsection{Terminology Coordination Section}

Subject-oriented terminography is done by the Terminology Coordination Section (TCS), National Language Service (NLS), Department of Arts and Culture (DAC). The Terminology Coordination Section is the national terminology office, with trained terminologists for each of the official South African languages. The TCS documents multilingual terminology in a variety of subject areas in a centralised national term bank. The TCS registers national projects in a national registry to avoid duplication of projects.

Terminologists usually receive in-house training presented by senior terminologists and external experts in terminology and lexicography. In 1995 the newly appointed African language terminologists, for instance, received intensive training presented by the Head: Systems Development and Research, who at the time was also teaching a terminology and lexicography module as parttime lecturer at the Department of African Languages, University of Pretoria. In 2007, as Director: Terminology Development and Standardisation at PanSALB, she also presented training modules on translation-oriented terminography (TOT) (cf. ISO 2002) to all language practitioners employed by the National Language Services, DAC.

Between 2001 and 2002 three senior terminologists of the TCS, NLS trained collaborators in all nine provinces to assist TCS with terminology development.

\subsubsection{Other organisations}

Other government, semi-government and non-governmental organisations (NGOs) such as National Parliament, the Department of Justice, Statistics South Africa, GCIS, Eskom, Tshwane Municipality, etc. also compile term lists dedicated to vocation-specific domains, e.g.

- National Parliament, Cape Town - the language practitioners (i.e. interpreters) compile term lists in various domains dealt with by parliament. The 
term lists are compiled in all official languages and terminology development is also done for South African Sign Language.

- State Law Adviser's Office, Department of Justice - the language practitioners compile term lists in all official languages. The terminology relates to legislation.

- Statistics South Africa - language practitioners compile term lists relating to statistics. These term lists assist the office when surveys need to be done.

- Provincial Departments and municipalities - language practitioners compile various term lists in the relevant provincial languages.

These and several other national and provincial offices received training on terminological principles and practice between 2002 and 2010, presented by the former Director: Terminology Development and Standardisation, PanSALB. She was also instrumental in the establishment of the Language Unit at the office of the State Law Adviser, Department of Justice.

The following model for the development of terminology represents the subject-oriented terminography process by a dedicated terminology office (cf. Diagram 1):

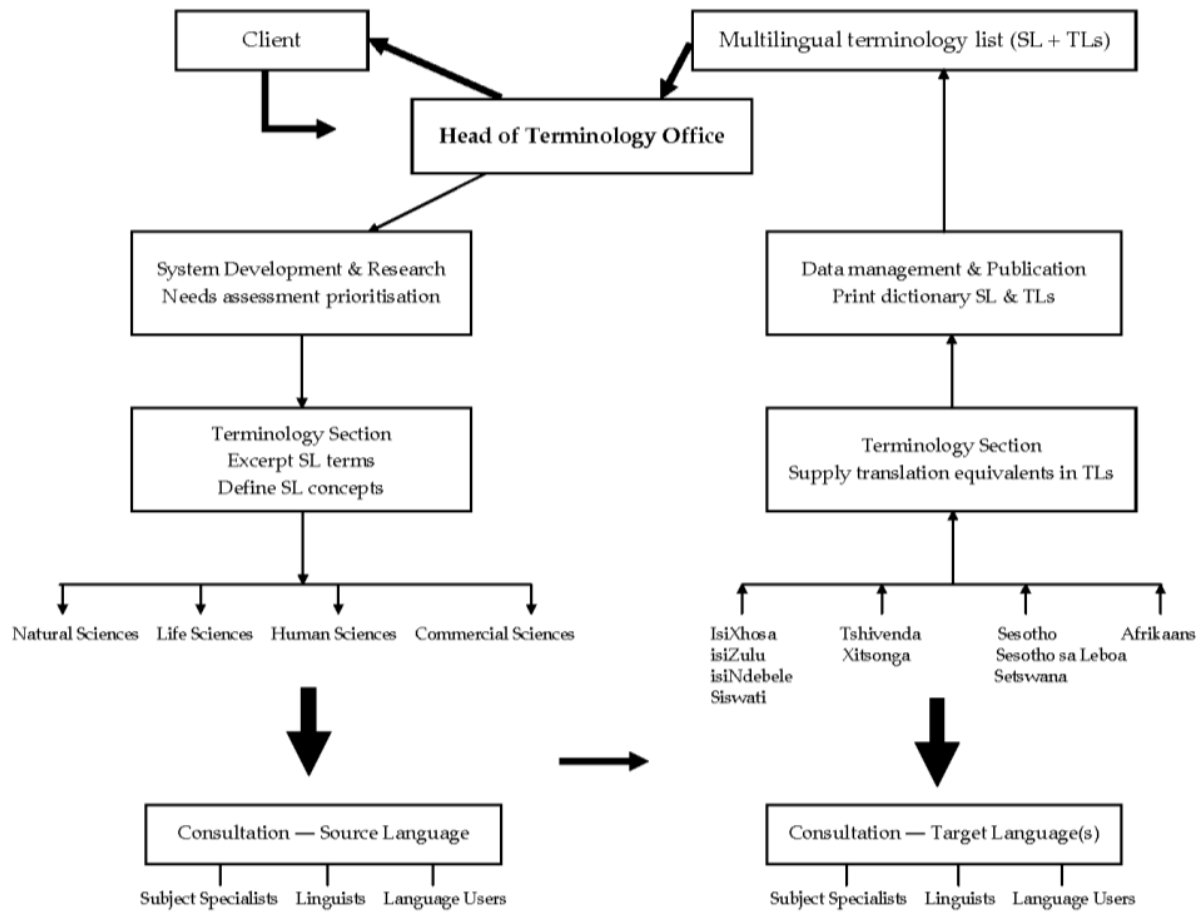

Diagram 1: Subject-oriented terminography process by dedicated terminology office 
The terminographical process described should be similar for all offices mentioned above (cf. Diagram 1 and paragraph 3):

- A term list should be compiled in response to a determined need. The need could be expressed by an external body, or the terminology office could determine a need by means of a needs assessment process.

- The subject area is demarcated and the target users determined.

- Source language (SL) terms are collected from relevant resources.

- SL terms are defined in consultation with subject specialists.

- The SL National Language Body verifies and authenticates the linguistic correctness of the SL in terms of word-forming principles, orthography, etc.

- The database is adjusted according to suggestions received.

- Target language (TL) equivalents and definitions are provided in consultation with subject specialists.

- The TL National Language Bodies verify and authenticate the linguistic correctness of the TL term equivalents in terms of grammar, word-forming principles, orthography, etc.

- The database is adjusted and updated according to suggestions received.

- The requested multilingual term list is presented to the external body (e.g. tertiary institution) or published in printed format for general usage by target users, or disseminated online (i.e. Internet).

\subsection{Independent terminology centres}

There are also private initiatives that provide terminology for tertiary institutions, e.g. projects by the Suid-Afrikaanse Akademie vir Wetenskap en Kuns (SAAWK) (South African Academy for Science and the Arts), the Centre for Political and Related Terminology in Southern African Context (CEPTSA) and the Centre for Legal Terminology in African languages (CLTAL). These centres all collaborate with the Terminology Coordination Section, National Lexicography Units, National Language Bodies and publishing houses.

- SAAWK - A bilingual Arts and Crafts dictionary was recently compiled by experts that worked under the auspices of the SAAWK. The dictionary has been completed and will be published soon. The ideal was to create a multilingual South African Arts Dictionary but the bilingual version was compiled first, since it was established in the work on several multilingual term lists that either the English or Afrikaans subject matter is freely consulted by the African language practitioners in the translation/creation of equivalents in their respective first languages (cf. SAAWK n.d.: 1). As art is universal, so its vocabulary is international and therefore there are numer- 
ous loanwords and transliterated concepts in the arts terminology, cf.

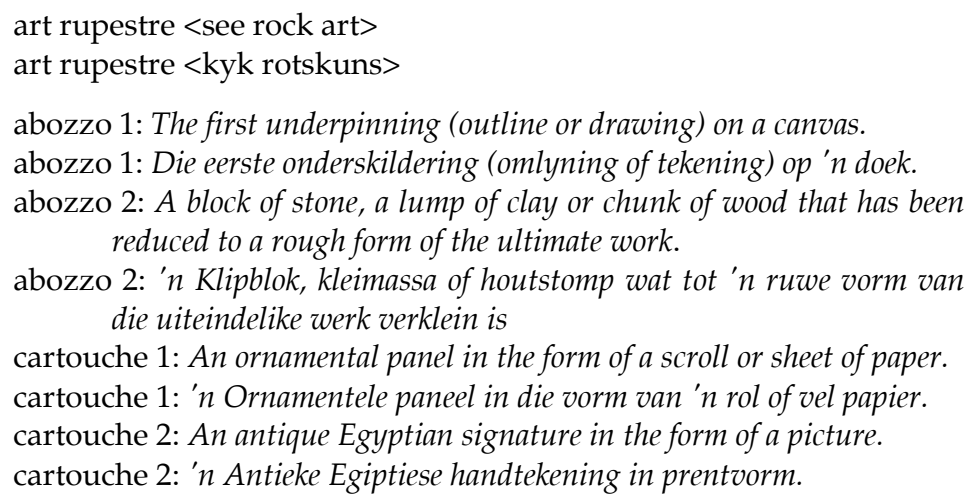

For the benefit of students, the name of the sub-discipline of art to which an entry belongs, was added, e.g. Architecture, Drawing, Painting, Ceramics... (cf. SAAWK n.d.: 5).

- CEPTSA is an independent centre that works under the auspices of the University of Johannesburg. A core group of subject specialists work in collaboration with a terminologist and linguist. The committee published a bilingual English/Afrikaans dictionary as well as a revised version on political terminology (cf. CEPTSA 2002; Botha, Le Clus and Venter 2011).

CEPTSA compiled an English SL term list with 1000 core terms and explanations and the data was translated into Afrikaans, Zulu and Northern Sotho (cf. Le Clus, Botha, Venter and Reyneke n.d.), cf.

majority rule. The exercise of power according to the will of the majority. meerderheidsheerskappy. Magsuitoefening volgens die wil van die meerderheid. ukubusa ngezwi leningi. Ukusetshenziswa kwamandla ngokuya ngentando yeningi. pušo ya bontši. Tiragatšo ya maatla go ya ka thato ya bontši.

A draft list containing English, Afrikaans and four of the African languages (Northern Sotho, Zulu, Xhosa and Tswana) was also compiled, cf.

abolition. The act of doing away with a practice such as capital punishment or slavery.

afskaffing. Die handeling om 'n praktyk soos die doodstraf of slawerny tot niet te maak.

phedišo. Modiro wa go fediša mokgwa wa go swana le kotlo ya lehu goba bokgoba.

ukuchithwa. Isenzo sokuchitha isejwayezi esithile njengokujeziswa ngakwezomnotho noma ubugqila.

ukubhangiswa. Isenzo sokuphelisa inkqubo enjengeyesigwebo sentambo okanye ubukhoboka.

phediso. Kgato ya go fedisa/khutlisa tsamaiso/tiragalo jaaka katlholelo leso kgotsa bokgoba.

The committee recently completed an explanatory list consisting of 2500 
English SL terms. This list has already been supplied with Afrikaans TL term equivalents and explanations. The bilingual explanatory list has been presented to African language terminologists to submit TL equivalents and explanations. The translation of the term equivalents of CEPTSA's new Verklarende Politieke Woordeboek/Explanatory Dictionary of Politics is done in collaboration with translators of the Language Units of the University of Johannesburg and the University of Stellenbosch and Juta Publishing House.

- CLTAL is an independent centre that works on criminal law, criminal procedural law and law of evidence. The compilation of the multilingual dictionary is done in cooperation with subject specialists such as lawyers, court interpreters and academics as well as language practitioners, such as linguists, terminologists and translators. CLTAL started with Northern Sotho as a first African language project in combination with English and Afrikaans, e.g.

$\begin{array}{lll}\begin{array}{l}\text { premeditated murder } \\ \text { polygraph }\end{array} & \begin{array}{l}\text { polaopeakanywa } \\ \text { seutoliamaaka }\end{array} & \begin{array}{l}\text { voorbedagte moord } \\ \text { poligraaf }\end{array}\end{array}$

Several legal professionals and linguists representing other African languages attend the quarterly meetings of the CLTAL and have already started supplying term equivalents and definitions in the other official languages, such as Tswana, South Sotho, Venda, and Tsonga. The first CLTAL publication will be a bilingual English-Afrikaans explanatory dictionary. CLTAL, however, aims to publish multilingual explanatory dictionaries containing all eleven official languages with the aid of its publisher (cf. Alberts 2008).

These centres follow the same terminographical process as described in paragraphs 3 and 4.1. The following model for the development of terminology represents the subject-oriented terminography process followed by independent terminology centres where internal collaborators work closely with external collaborators (cf. Diagram 2):

\begin{tabular}{|c|c|}
\hline Independent centre: & $\begin{array}{l}\text { External collaborators: } \\
-\quad \text { Other subject specialists }\end{array}$ \\
\hline Internal collaborators: & - Linguists \\
\hline - Subject specialists & - NLUs \\
\hline - Linguists & - NLBs \\
\hline - Language practitioners & - TCS, NLS, DAC \\
\hline - Terminologists & _ Publishing houses \\
\hline
\end{tabular}

Diagram 2: Subject-oriented terminography process by independent terminology centres 
The majority of the work relating to the terminographical process (cf. paragraphs 3 and 4.1 and Diagram 1) is done by the subject specialists themselves and they only receive minor linguistic and terminographical assistance from the terminologist and/or linguist assigned to the projects.

\subsection{Terminology centres at tertiary institutions}

There are several tertiary institutions that are already realising the value of multilingual polythematic terminology in the under- and postgraduate environment. Yet, a lot of spade work still needs to be done by several major universities before they could really embark on the development of terminology.

\subsubsection{Current terminology work at tertiary institutions}

The terminographical work done by the Stellenbosch University Language Centre is an excellent example of the kind of terminological assistance that could be provided to lecturers and students.

In February 2006 the former Director: Terminology Development and Standardisation, PanSALB was invited to the Stellenbosch University Language Centre to present a three-day training session on terminological principles, procedures and practices of terminography in African languages (cf. Sibula n.d.: 24).

Since the training, the Unit for IsiXhosa of this Language Centre had already compiled several trilingual Xhosa-English-Afrikaans terminology lists. The terminology lists include three generic term lists, i.e. Generic Academic list, Generic Administrative list and a List of Faculties, Departments, Academic Divisions together with Administration and Services - the typical terminology students would need to orientate themselves when enrolling at the university. Five trilingual subject-specific term lists have also already been compiled, namely Social Work, Sociology, Psychology, Law and Economic and Management Sciences, cf.

$\square$ normative \{establishing a norm or standard \}

ummiselo-sithethe \{kukumisela isithethe nomgangatho\}

normatief \{vasstelling van ' $n$ norm of standaard\}

adolescence \{life phase beginning at puberty and ending in adulthood\}

ukufikisa \{isigaba sobomi esiqala ekufikeleleni ebudaleni nesiphela ngobuntu obudala\}

adolessensie \{lewensfase wat begin by puberteit en eindig in volwassenheid\}

Three trilingual sport-related term lists were also compiled: Soccer, Cricket and Rugby.

The terminologist consults experts to obtain terminological data. The sub- 
ject specialists submit core and problematic concepts and senior students assist with the defining of terms in SL (English). The SL terms and definitions are then provided with Xhosa and Afrikaans term equivalents and definitions. The IsiXhosa Unit is responsible for term creation processes and quality control. The various departments decide how to market and disseminate the terminology lists, e.g. online or hard copies (cf. Sibula n.d.: 4-28).

In 2009 the former Director: Terminology Development and Standardisation, PanSALB was invited to Rhodes University, Grahamstown to present terminology training to enable the University to put multilingual terminological data on various subjects on a blog for utilisation by academics and students.

Rhodes University introduced several programmes to develop subjectrelated terminology:

- Teaching programme - this programme consists of a generic course in Xhosa as an additional language in subject-related courses such as pharmacy, law, journalism and media studies, education and psychology.

- Terminology lists - English-Xhosa glossaries or term lists are compiled to support learning in English as language of learning and training. Term lists were already compiled for Earth Science, ICT, Politics and Cell Biology.

- Teaching of Xhosa - the teaching of, and in Xhosa as first language in subjects such as linguistics, literary studies, translation studies, lexicography and sociolinguistics.

- Postgraduate research - students are encouraged to do their subjectrelated research through medium of Xhosa (cf. Maseko 2012: 17).

The former Director: Terminology Development and Standardisation, PanSALB presented either terminology training or urged several other tertiary institutions to start terminology development programmes at their institutions, such as University of Pretoria (2005-2007); PRAESA, University of Cape Town (2005); Tshwane University of Technology (2006); Language Research and Development Centre, Nelson Mandela Metropolitan University (2008); University of South Africa (2009); University of the Free State (2010), and Cape Peninsula University of Technology (2012).

The following lessons were learned from existing terminology-related centres at tertiary institutions:

- Terminology is a strategic resource.

- Terminology development makes a contribution to the development and promotion of the official languages.

- Terminology development is a direct response to the Republic of South Africa's Constitution regarding the development of the official languages.

- All official languages could be developed for use in higher education. 
- The development of African languages into languages of learning and training is a difficult and cumbersome but necessary exercise.

- Interactive collaboration is needed during the terminology development process.

- Students use and appreciate the terms and definitions provided in the official African languages.

- Lecturers who are monolingual could promote the use of other languages in class by using bilingual or multilingual teaching aids.

- Language is a symbol of national pride and the use of the indigenous languages builds confidence (cf. Alberts 2012b; Sibula n.d.: 3; Maseko 2012: 32).

\subsection{An integrated model: the establishment of terminology centres at terti- ary institutions}

It is proposed that terminology centres should be developed at language centres or schools of languages at tertiary institutions to present terminology training, to do terminology and terminography-related research and to assist subject-related faculties with the compilation and dissemination of subjectrelated term lists. The aim should be to train terminologists who could assist with the development of the eleven official languages into functional languages of learning and training and to develop multilingual polythematic terminology.

\subsubsection{Terminology training}

The latest legislation regarding the use of languages (Act of 2013) ensures job creation possibilities for language practitioners (cf. Government Gazette 2012; 2013). But despite legislation to enhance the language practice, it seems as if fewer students enrol for language courses. The terminology practice urgently needs trained and knowledgeable terminologists.

Terminology training is of importance for language practitioners who would like to work at the Terminology Coordination Section of the National Language Service, Department of Arts and Culture or at any of the language units at national and provincial government departments that need to adhere to current legislation. All government institutions will have to develop the terminology of the subjects related to their fields of expertise and vocation. These terms will have to be in at least three of the official languages.

Only a few tertiary institutions in South Africa are currently dealing with terminology training. Most of the terminology courses are modules within either a linguistics course, a course in translation studies or in lexicography. Given the urgent need for terminology development, there should be dedicated terminology courses stretching from undergraduate level to doctoral studies. These courses should form part of the curricula of schools of languages. Stu- 
dents studying any course within a school of languages, such as Afrikaans, African Languages, English, French, German, Linguistics, Roman Languages, etc., should be able to do a theoretical and practical course in terminology and terminography.

Terminology students should get training in inter alia:

- the theoretical principles and practice that form the basis of terminology work and terminography

- metalexicography

- the difference between lexicography and terminography

- dictionary structures (macro-, micro- and medio-structures)

- typology of dictionaries

- the function of dictionaries

- ontological relationship between concepts

- primary term creation (SL)

- secondary term creation (TL)

- communicative value of terminology

- cultural differences

- compilation of monolingual, bilingual and multilingual dictionaries (cf. Alberts 2002; 2004a and b; 2005a, b and c; 2007).

Terminology students should also get practical experience in terminography work by:

- applying their acquired linguistic knowledge and terminographical skills;

- excerpting subject-related terms from various resources (e.g. text books, study material, journals, dissertations, etc.) - this is an exercise in terminology harvesting methods;

- defining terms to ensure that the content of the concept is reflected in the definition - this is an exercise in the usage of different definition methods;

- doing assignments on the compilation of a source language term list of a specific domain - this is an exercise in primary term creation and any of the languages could be used as source language;

- doing an assignment in collaboration with other students by compiling a bilingual or multilingual term list - this is an exercise in secondary term creation;

_ evaluating the compiled term lists of fellow students - this is an exercise in 
dictionary criticism and the students can learn from their own mistakes and those of other students (cf. Alberts 2002; 2004a and b; 2005a, b and c; 2007).

The value of terminology training for students:

- They would recognise terminology work and terminography as a career opportunity.

- They would

- be trained in the basic theories, principles and practice that govern terminology and terminography;

- be trained in the practice of the compilation of different types of dictionaries;

- learn the value of collaborative work;

- get to know the typical working environment of a terminologist and what to expect when such a career is pursued;

- learn how to deal with peer group criticism in a constructive way;

- learn the importance of working in collaboration with and consulting subject specialists, linguists, language practitioners, language structures (e.g. NLBs, NLUs, TCS);

- familiarise themselves with different language structures (TCS, NLBs, NLUs, PLCs) and language units and to differentiate between these structures;

- be skilled to work at terminology-related institutions and they would require less in-service training.

- Students interested in a career in terminology and terminography could enrol for postgraduate courses (cf. Alberts 2005c).

The value and need for terminology training is underpinned by the TermTrain initiative of TermNet (an international network for terminology), in cooperation with UNESCO and South African role-players (September 2005 and February 2006). The aim with this terminology training was to emphasise the value of terminology development and training among language practitioners (cf. Alberts 2007).

It is not possible to compile subject-related dictionaries without properly trained terminologists (cf. Alberts 2007).

\subsubsection{Value of terminology training and development}

\subsubsection{School of Languages or Language Units at tertiary institutions}

Terminology training and the development of term lists could be beneficial to 
the school of languages/language unit:

- A school of languages or a language unit would become known as a terminology development centre.

- Draft term lists created by the students/terminologist could be sent to subject specialists, academics, linguists, language practitioners, and language communities for comments, amendments and approval (e.g. NLB approval).

- Verified term lists could be submitted to TCS, NLUs and disseminated to other faculties and departments via the Internet.

- Other faculties and departments would recognise the value of the school of languages/language unit for their own work.

- Schools of languages would enrol more students since a practice-driven course would encourage students (cf. Alberts 2002; 2004a and b; 2005a, b and c; 2007).

\subsubsection{Other faculties and departments at the specific tertiary institution}

Lecturers describe concepts that are usually foreign to students. These concepts are sometimes defined in study material or textbooks but not necessarily in the student's first language. Terminology training and development could, therefore, also be beneficial to other faculties and departments:

- Bilingual and multilingual term lists compiled by the students/terminologist would contain relevant terms and definitions (i.e. excerpted for study guides) and would be disseminated to subject-related departments and faculties.

- Various departments and faculties would become aware of the value of standardised multilingual polythematic terms and definitions.

- Students enrolled in subject-related departments and faculties would be able to understand difficult concepts in their first languages.

- Information retrieval would be easier in the student's first language.

- Even though students have to write their exams in another/second language, they would at least be able to understand the conceptual contents, because the concepts would be clear and internalised.

- Information conveyance and retrieval is paramount in the first language.

- Students would become language conscious and could even supply term lists and glossaries in scripts, dissertations and theses. These term lists could be submitted to the school of languages/language unit at the tertiary institution in a centralised database and disseminated to other stu- 
dents. These term lists could also be submitted to the national term bank at TCS, NLS, DAC for (inter)national dissemination (cf. Alberts 2002; 2004a and b; 2005a, b and c; 2007).

\subsubsection{Value for other faculties and departments at other tertiary institutions}

This kind of terminology training and development could also be beneficial to other tertiary institutions that do not present terminology training courses:

- Terminology could be disseminated through virtual networks to other tertiary institutions that could utilise the multilingual terms and definitions.

- Lecturers and students could comment on the available terminology and adjustments could be made.

- Term equivalents and explanations could be supplied in other languages that might not be available yet.

- The terms and definitions could be standardised through frequent usage.

- The terms could be ulitised for interpreting and translation services.

- Duplication of subject-related work and the proliferation of terms for the same concept could be avoided (cf. Alberts 2002; 2004a and b; 2005a, b and c; 2007).

\subsubsection{Value for language offices}

Language offices, (non-)governmental language units and private enterprises (e.g. publishing houses) could also benefit from this terminology training and development:

- Terminologists lacking proper training could enrol for terminology courses.

- The basic theories, principles and practices of terminology and terminography are addressed in the terminology course, which decreases the need for in-service training.

- Different types of language practitioners (translators, lexicographers, interpreters, editors, journalists) could enrol for the terminology course seeing that they utilise and need terms in their working environments.

- The different language structures (NLUs, NLBs, TCS, national and provincial language units) could evaluate the course and give feedback to the school of languages/language unit regarding specific needs or content.

- TCS, NLUs and publishing houses would have a list of potential termi- 
nologists.

- All these offices could utilise the term lists that are developed.

- The terminology that is created would enhance the potential of the official languages to develop into functional languages in the workplace and into functional languages of science and technology (cf. Alberts 2002; 2004a and $b ; 2005 a, b$ and c; 2007).

\subsubsection{Value for Human Language Technologies}

Since the term lists would be made available online in electronic format on the Intranet, Internet, etc. there would also be benefits for the national human language technologies virtual network:

- Term lists would be available in electronic format, e.g. at the web pages of tertiary institutions, and could, after the verification and authentication by subject specialists and other experts (e.g. NLBs), become part of the virtual network of the HLT programme.

- As part of the HLT virtual network these multilingual polythematic terms would be available to a variety of users.

- The official South African languages would be in a better position to develop into functional languages of science and technology.

- The official South African languages would also become available and recognised internationally and would even be available on the World Bank of International Terms (WBIT) (cf. Alberts 2007: 8).

- It is noted that Dutch-speaking countries such as the Netherlands and the Flemish-speaking part of Belgium are interested in Afrikaans terminology and Afrikaans terms and explanations would therefore also be internationally available to the Dutch-speaking communities.

\subsection{Proposed integrated model}

The process described above will train students at tertiary institutions in the basic theory, principles and practice of terminology and terminography and will not only provide trained terminologists to language offices, but would also continuously supply multilingual polythematic terms to various target user communities. This process could enhance the terminology development process.

Activities associated with an integrated terminology training and development model will have to include the following aspects:

- dedicated terminology training, initially undergraduate, but later also postgraduate to all language practitioners-in-training 
- practical terminology work that incorporates subject-specific faculties and departments in the development of subject-related terminology lists

- research, especially in terms of the problematic issues relating to the development of terminology in the African languages

- training of lecturers in the theory, principles, practice and management of terminology

- cooperation with the National Language Bodies regarding the languagespecific verification and authentication of term equivalents and definitions in the various official languages

- cooperation with the Terminology Coordination Section, National Language Service, Department of Arts and Culture, National Lexicography Units, language units at national and provincial government departments, publishing houses, private initiatives, etc.

- national and international dissemination of multilingual polythematic terminology via the human language technologies virtual network (cf. Alberts 2002; 2004a and b; 2005a, b and c; 2007).

The following integrated model for the development of terminology represents the proposed subject-oriented terminography process by terminology centres at tertiary institutions (cf. Alberts 2005c; Diagram 3):

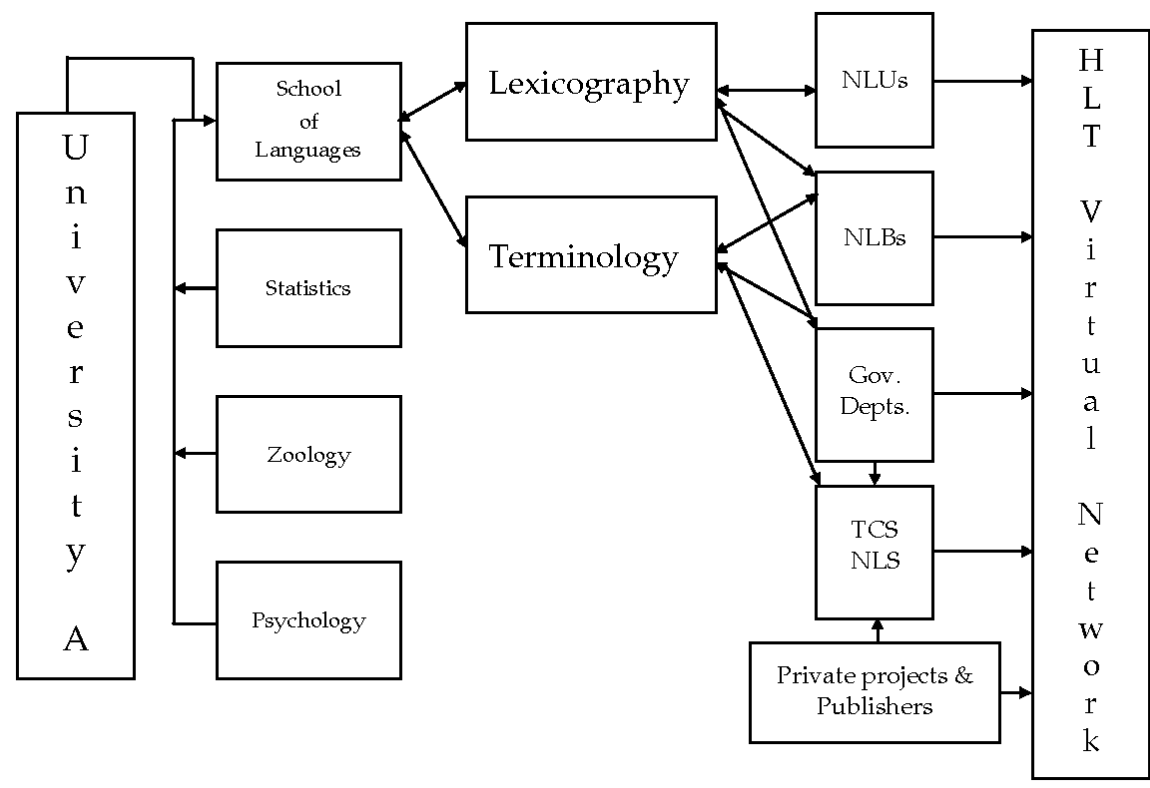

Diagram 3: Subject-oriented terminography process by terminology centres at tertiary institutions 
The terminology development process entails the following procedures:

- Term extraction (harvesting/excerption) in the SL from textbooks, tutorials, study guides, dissertations, doctoral theses. These terms should be

- those with high frequency in the selected texts

- representing concepts considered critical for students to grasp

- those which, according to the lecturer, are core terms relating to the subject

- those which, according to the students, are difficult to grasp in the subject.

- Language students, with the assistance of students majoring in a given subject field, should define the concepts in the SL.

- The definitions should be verified by the language, as well as subject field lecturers.

- The SL terms and definitions are then translated into the TL(s) by language students and verified by the lecturer. Different language departments could assist in the process (i.e. English, Afrikaans, African languages, and even foreign languages such as Roman languages (to determine the etymology of terms)).

- The IT department could assist with database creation, maintenance and data dissemination, i.e. e-learning platforms, Intranet or Internet, where lecturers and students could rate the terms and definitions and make recommendations for improvement.

- The term lists/glossaries should also be presented to the relevant National Language bodies for the verification of language-related principles such as adherence to word-forming principles, spelling and orthographic conventions.

- Term lists or glossaries could be included in tutorials, study guides and textbooks.

- The term lists or glossaries could be disseminated to other tertiary institutions, to the Terminology Coordination Section, other language units, national lexicography units, publishing houses, etc. via the human language virtual network. This would enable penetration of terms in subject fields and in the official languages, which would in the end lead to the standardisation of these terms (cf. Alberts 2005c; 2012a and b).

Although various models were discussed, it should be noted that national collaboration is needed. An integrated model that includes both terminology training and development is therefore proposed. There should be cooperation and interaction and terminological data should be shared. Care should be taken 
that there is no duplication of projects. Duplication could result in concepts being denoted in different projects by different SL terms and TL equivalents. This will result in a proliferation of terms denoting the same concepts and it will prevent the standardisation of terminology: this could lead to terminological chaos.

The Department of Higher Education (2010: 8) recognises the cost of developing the official South African languages into languages of instruction and tuition. It also relates the overall student numbers to this developmental issue and proposes regional collaborative frameworks and initiatives (cf. Maseko 2012).

\section{Conclusion}

It is argued that people understand concepts best in their first language and that it is therefore easier to convey information (i.e. a lecture) through the medium of the first language of both the lecturer and the student. It is essential to internalise information first in the first language, before switching to a second or third language. It is easier to switch to another language (e.g. English) later in life (e.g. working environment) if information was internalised through the first language.

The article focussed on terminology development in tertiary education. Different models for the development of terminology for this educational phase were proposed in order to supply standardised polythematic terminology for tertiary institutions in the various official languages of South Africa. The hegemony of English unfortunately is often the cause why the other official languages struggle with terminology development. The processes described in the three models that culminated in an integrated model will ensure that the official languages will develop into functional languages of higher learning.

The training of terminological theory, principles and practice also received attention. It is argued that schools of languages at tertiary institutions should also present terminology training as an option in language studies. Students following such a course would be suitably trained to join terminology offices and less time would be spent on in-service training. Tertiary institutions would also benefit from terminology courses because students following the course would be able to submit valuable outputs to other faculties and departments. Terminological data could be disseminated to other tertiary institutions and various institutions could collaborate and share data. The virtual human language technologies project could also benefit by receiving multilingual polythematic terminological data on a regular basis and could disseminate the data to subject specialists, linguists, language practitioners and the broader language community.

Both the subject-related language community and the broader language community could benefit from the processes described in the article, since multilingual polythematic terms would be made available for better communi- 
cation, minority languages will develop into functional languages in the higher echelons of science, technology, economy, law, etc., and the official South African languages would be globally available as functional (inter)national languages, via the HLT virtual network.

\section{Bibliography}

Alberts, M. 2002. Lexicography and Terminology Training at University Level. Unpublished Document. Pretoria: PanSALB.

Alberts, M. 2004a. Envisaged Lexicography and Terminology Training Centre, Department of African Languages, University of Pretoria, in conjunction with PanSALB. Unpublished Document. Pretoria: PanSALB.

Alberts, M. 2004b. Establishment of a Lexicography and Terminology Training Centre at the Department of African Languages, School for Languages, University of Pretoria. Unpublished Document. Pretoria: PanSALB.

Alberts, M. 2005a. Envisaged Lexicography and Terminology Training Centre, Department of African Languages, University of Pretoria, in conjunction with PanSALB. Unpublished Document. Pretoria: PanSALB.

Alberts, M. 2005b. Training Initiative for Lexicography, Terminology, Human Language Technology and Translation. Unpublished Document. Pretoria: PanSALB.

Alberts, M. 2005c. Terminologieopleiding op universiteitsvlak. Paper presented at the SAAWK Symposium, 23-24 June 2005, TE Building, Garsfontein, Pretoria.

Alberts, M. 2007. Voorstel vir die vestiging van 'n Terminologiesentrum aan die Universiteit van Pretoria. Unpublished document. SAAWK: Pretoria.

Alberts, M. 2008. Centre for Legal Terminology in African Languages (CLTAL). Paper read at the PanSALB Conference on Terminology Standardisation, 25-26 September 2008, Gallagher Estate, Midrand.

Alberts, M. 2012a. Terminology as an Aid in Mother-tongue Education. Paper read at the 17th International Afrilex Conference, 3-5 July 2012, SRC Chambers, University of Pretoria, Pretoria.

Alberts, M. 2012b. Terminology as an Aid in Teaching and Learning. Paper read at the Closed Workshop on Verification of Scientific Terminology and International Translation Day, 28 September 2012, CPUT, Bellville Main Campus.

Botha, S., P. le Clus and A.J. Venter. 2011. Modern Political Dictionary. Nuwerwetse Politieke Woordeboek. George: Digi Press.

Cluver, A.D. de V. 1982. Aspekte van 'n teorie oor terminologie. Language Practitioner 2: 74-90.

Cluver, A.D. de V. 1983. Konsep: Terminologiehandleiding. Unpublished Document.

Department of Arts and Culture. 2011. Presentation to the Portfolio Committee: Arts and Culture on the South African Languages Bill 2011, 16 November 2011. Pretoria: Department of Arts and Culture.

Department of Higher Education and Training. 2010. African Languages Roundtable. Paper presented at the African Languages Roundtable, 22 October 2010, Unisa, Sunnyside Campus, Pretoria.

Department of Higher Education and Training. 2012. Green Paper for Post-school Education and Training. Pretoria: Government Printer. 
Department of Sport, Recreation, Arts and Culture. 2005. Language Policy Framework of the Gauteng Provincial Government. Johannesburg: Gauteng Provincial Government.

Government Gazette. 2012. Use of Official Languages Act 12 of 2012. Government Gazette, Vol. 568, No. 35742, 2 October 2012. Cape Town: The Presidency.

Government Gazette. 2013. SA Use of Official Languages Act - Proposed Regulations. Government Gazette 26, Notice 411 of 2013, No. 36392, April 2013: 56-67. Cape Town: National Parliament.

ISO. 2002. ISO 12616.2002. Translation-oriented Terminography. International Organization for Standardization, ISO/TC37/SC2.

Le Clus, P., S. Botha, A.J. Venter and B. Reyneke. n.d. Multilingual Modern Political Dictionary: 1000 Core Definitions. Auckland Park: University of Johannesburg.

Maseko, P. 2012. Advancing the Use of African Languages in SA Higher Education: Strategies, Challenges and Opportunities. Paper read at the Closed Workshop on Verification of Scientific Terminology and International Translation Day, 28 September 2012, CPUT, Bellville Main Campus.

SAAWK. n.d. Bilingual Arts Dictionary. English-Afrikaans/Afrikaans-English. Unpublished Manuscript.

Sibula, P.M. n.d. Terminology development: Challenges, skills, strategies and stakeholders' role. Unpublished Paper. Unit for IsiXhosa, Stellenbosh University Language Centre.

Statistics South Africa. 2013. Multilingual Statistical Terminology. Pretoria: Statistics South Africa.

\section{Internet Reference}

http://www.loc.gov/standards/iso639-2. Accessed September 2013. 